УДК004.9:378

Глушак Оксана Михайлівна

викладач кафедри інформаційних технологій та математичних дисциплін

Київський університет імені Бориса Грінченка, м. Київ, Україна

oksana_glushak@ukr.net

\title{
ЗАСТОСУВАННЯ МЕРЕЖНИХ ТЕХНОЛОГІЙ В НАВЧАЛЬНО-ВИХОВНОМУ ПРОЦЕСІ ВНЗ
}

\begin{abstract}
Анотація. У статті розглянуто сервіси мережних технологій, проаналізовано різні способи застосування вікі-технологій, блогів, вебінарів, систем дистанційного навчання, зі створенням електронних навчальних курсів, у навчально-виховному процесі вищої школи. У результаті дослідження визначено, що основними завданнями застосування мережних технологій в навчально-виховному процесі вищого навчального закладу є: створення стійкого пізнавального мотиву, розвиток творчого потенціалу студентів, підвищення наочності навчального матеріалу, інтенсифікація всіх рівнів навчального процесу, розширення і поглиблення змісту навчання, індивідуалізація та диференціація навчання.
\end{abstract}

Ключові слова: інформатизація; інформаційно-комунікаційні технології; web-2.0; вікі; блоги; вебінар.

\section{1. ВСТУП}

Постановка проблеми. Упровадження сучасних інформаційно-комунікаційних технологій в освітню систему України і формування єдиного інформаційно-освітнього простору - одні з пріоритетних напрямів сучасної державної політики. На думку академіка В. Кременя, «інформаційно-комунікаційні технології є тим технологічним базисом, на якому потрібно забезпечувати всім громадянам нашої країни рівний доступ до знань» [1]. Це дає підстави говорити про широке застосування сучасних інформаційно-комунікаційних технологій (IКТ) в навчально-виховному процесі закладів освіти. Зокрема, мережні технології набули широкої популярності серед користувачів за останні роки і суттєво впливають на комунікацію між студентами i викладачами. Спільна робота 3 документами, обговорення тем у блогах і на форумах дозволяє залучати й мотивувати до навчальної діяльності студентів.

Перед викладачами розкривається більше можливостей із застосуванням сервісів web 2.0: використання відкритих, безкоштовних і вільних електронних ресурсів педагогічних програмних засобів, електронних підручників, мовних ігор, відео й аудіо файлів, які можуть бути застосовані у навчальному процесі; самостійне створення мережного контенту - текстів, презентацій, малюнків, фотографій, відео й аудіо матеріалів; участь у нових формах навчально-пізнавальної діяльності, що пов'язано з пошуком іншомовної інформації, так і створення й наповнення власного контенту; участь у професійних наукових спільнотах, яка розширює поле професійної діяльності і співробітництва $з$ іншими фахівцями $[2,246]$.

Для успішного застосуванням мережних ресурсів як студентами, так i викладачами й оптимізації навчально-виховного процесу необхідним є дослідження основних напрямів застосування сервісів web 2.0 на різних етапах навчального процесу.

Аналіз останніх досліджень i публікацій. Застосування інформаційнокомунікаційних технологій розглянуті в науковій і психолого-педагогічній літературі досить грунтовно. Зокрема, розроблені концептуальні й психологічні основи застосування інформаційних технологій в освітньому процесі (В. Беспалько, 
Р. Гуревич, М. Жалдак, В. Красильникова, Н. Морзе, Е. Полат, Н. Тализіна, М. Чошанов та ін.); висвітлені теоретичні основи розробки і застосування засобів інформатизації освіти (А. Ашеров, Г. Бордовський, Т. Бороненко, В. Ізвозчиков, О. Зиміна, Д. Матрос, С. Панюкова, Н. Тверезовська та ін.); розкриті науковопедагогічні підходи до навчання студентів вищих навчальних закладів із застосуванням інформаційних технологій (А. Андрєєв, О. Гурова, В. Котенко, А. Кравцова, Д. Махотін, К. Осадча, А. Пеньков, Ю. Рамський, М. Федюшина, Є. Ширшов та ін.); проаналізована роль інформаційно-телекомунікаційних технологій у підготовці вчителів (Р. Горбатюк, 3. Кучер, М. Галанова, Є. Патаракін, І. Петрицин, О. Спірін, Є. Тарасова, С. Трусов та ін.).

Мета статті: розглянути сервіси мережних технологій і визначити шляхи їх застосування у навчально-виховному процесі вищого навчального закладу.

\section{2. МЕТОДИ ДОСЛІДЖЕННЯ}

Під час дослідження було використано такі методи: аналіз теоретичних джерел проблеми застосування мережних технологій у навчально-виховному процесі, узагальнення i систематизація досвіду застосування мережних технологій у навчальному процесі ВНЗ.

\section{3. РЕЗУЛЬТАТИ ДОСЛІДЖЕННЯ}

У ВНЗ широкого застосування набули сервіси мережних технологій - web 2.0, які виступають важливим інструментом оптимізації навчально-виховного процесу. Розглянемо приклади сервісів web 2.0, які можна застосовувати в навчально-виховному процесі. Словники (http://hrinchenko.com/, http://www.rozum.org.ua/, http://www.sum.in.ua/); перекладачi (www.pereklad.online.ua, www.pereklad.online.ua, http://www.lingvo.ua/ru); енциклопедіï (http://www.krugosvet.ru/, http://www.megabook.ru/, $\quad$ http://www.encyclopedia.ru/); бібліотеки (http://www.nbuv.gov.ua/, http://rsl.ru/, http://onesearch.library.utoronto.ca/, http://elibrary.worldbank.org/content/books); карти знань або карти розуму (https://bubbl.us, http://www.mindmeister.com/ru, http://www.mindomo.com/); електронна пошта; системи дистанційного навчання (http://www.intuit.ru/); освітні ресурси online (www.britishcouncil.org/ukraine.htm); вебінари (http://www.wiziq.com/); менеджери миттєвих повідомлень (Qip, ICQ, Miranda, Skype); пошукові системи і тематичні каталоги (https://www.google.com.ua/, http://meta.ua/, http://www.ukr.net/); соціальні мережі (http://vk.com/, https://new.myspace.com/, https://twitter.com/, https://twitter.com/); мережні педагогічні спільноти (http://www.pil-network.com/, http://metodportal.net/, http://www.it-n.ru/, http://metodisty.ru/) блоги ((http://www.livejournal.ru/, http://www.blogger.com); вікі ресурси (Вікісховище (http://commons.wikimedia.org/), Віківерситет (http://ru.wikiversity.org/), Вікісловник (http://uk.wiktionary.org/), Вікіцитати (http://uk.wikiquote.org), Віківиди (http://species.wikimedia.org), Вікіновини (http://uk.wikinews.org), Вікіпідручник (http://uk.wikibooks.org), Вікіосвіта (http://eduwiki.uran.net.ua)); соціальні закладки (http://bobrdobr.ru/, http://moemesto.ru/, http://myscoop.ru/, http://www.100zakladok.ru ); сховища даних (http://www.youtube.com/, http://teachertube.com/, http://www.slideshare.net/, http://iteach.com.ua/ ); спільна робота 3 документами (accounts.google.com, http://office.microsoft.com/en-us/web-apps/); географічні сервіси (http://wikimapia.org, http://www.google.com/earth/index.html). 
За допомогою блогів, вікі ресурсів користувачі самостійно можуть створювати i редагувати контент, інші користувачі можуть використовувати, оцінювати, коментувати та редагувати, тобто контролювати процес формування інформаційних ресурсів.

Соціальний сервіс Вікі може бути застосований у педагогічній практиці різними способами:

- подання, розширення та анотування навчальних матеріалів, тобто створення приміток, коментарів і анотацій на полях лекцій, які можуть складати викладачі і студенти;

- спільне створення віртуальних екологічних (географічних, історичних тощо) екскурсій студентами;

- колективне створення творчих робіт;

- колективне створення студентських енциклопедій [3].

Д. Вайнер визначив блоги як веб-сайти, які легко створювати й оновлювати користувачам, які не мають технологічних навичок і знань [4].

Блоги виконують такі функції: комунікативну; самопрезентації; розваги; групування й утримання соціальних зв'язків; мемуарів; саморозвитку або рефлексії; психотерапевтичні [5, с. 75].

У викладанні мовних дисциплін виокремлюють такі три типи блогів [6]:

- викладацький блог підтримується викладачем студентської групи. У ньому можуть розміщуватися програми навчальних курсів, навчально-методичні матеріали для майбутніх філологів або самого викладача, завдання для студентів;

- аудиторний блог — це блог, який підтримується спільними зусиллями викладача і студентів;

- студентський блог - це блог, який вимагає великої кількості часу й зусиль від викладачів, але це найефективніший засіб у викладанні мовних дисциплін. Він створюється майбутніми філологами самостійно вдома або за підтримки викладача в комп’ютерному класі. Тут перед студентами відкриваються можливості їх самореалізації, оскільки індивідуальні блоги стають їхнім особистим мережевим простором. Перевага студентського блогу полягає в тому, що він надає майбутнім філологам свободу вибору тем опублікованого матеріалу, підвищує почуття відповідальності за його зміст [6].

Розглянемо приклад застосування блогів у процесі формування інформаційної культури під час вивчення дисциплін інформаційно-комп'ютерного циклу. Завдання полягає у створенні блогу на задану тему і коментуванні блогів своїх одногрупників. Кожен зі студентів групи має свою тему для розкриття у блозі: здійснює пошук інформаційних даних, аналізує й розміщує відповідно структурований матеріал. Усі студенти групи у заданий період часу мають відвідати блоги своїх одногрупників, оцінити якість наповнених матеріалів і прокоментувати їх. Результати виконання даного завдання організовуються до online документа, доступ до якого мають всі студенти. Документ зі спільним доступом включає такі відомості: прізвище студента, тема його дослідження, його нік на сайті і критерії оцінювання блогу іншими студентами. Для комунікації між студентами і викладачем можна використовувати електронну пошту, менеджери миттєвих повідомлень і засоби комунікації, вбудовані в систему дистанційного навчання. У результаті виконання такого завдання кожен 3 учасників навчального процесу має навчитися: здійснювати пошук інформаційних даних, структурувати їх, створювати блоги, працювати зі спільними документами i здійснювати аналіз блогів інших студентів групи. 
Для узагальнення і систематизації знань із заданої теми, з метою формування інформаційної культури, студентам можна запропонувати завдання: створити карту знань, яка буде включати основні положення даної теми. У результаті виконання такого завдання кожен з учасників навчального процесу має навчитися: здійснювати пошук інформаційних даних, структурувати їх та працювати з online сервісами, які дозволяють створювати карти знань (карти розуму).

Електронні бібліотеки, енциклопедії, словники і перекладачі - електронні, відкриті мережні ресурси, які є дуже популярними серед користувачів Інтернету, оскільки містять доступ до безмежного ресурсу інформаційних даних. Ці дані актуальні, різнобічні (з різних галузей), представлені у різних формах та доступні у будь-який час. Зокрема, актуальною $є$ технологія проведення вебінару.

В. Кухаренко зазначає, що вебінар — це «віртуальний» семінар, організований за допомогою Інтернет-технологій. Вебінару властива головна ознака семінару інтерактивність [7]. Вебінар — це особливий тип відео конференції. Під час вебінару викладач знаходиться за комп'ютером, який укомплектований веб-камерою i мікрофоном, і проводить спілкується 3 аудиторією у аудіо-відео форматі й чаті на одному 3 online ресурсів, який надає такі послуги. Під час проведення вебінару викладач може демонструвати будь-який матеріал (схеми, текстові документи, електронні таблиці, презентації, відео тощо), завантажуючи його в середовище вебінару, застосовувати «дошку для малювання», проводити опитування. За правильної організації і грамотної методики проведення вебінари сприяють глибокому зануренню в процес, досягненню ефективних результатів.

Перевагами вебінару перед іншими формами організації підготовки:

- слухач дістає можливість освоювати нові знання й уміння і спілкуватися 3 викладачем, знаходячись географічно у будь-якому місці - у звичних i комфортних умовах;

- вебінар - це економічно вигідна форма організації навчання. Для участі у вебінарах потрібний комп'ютер, обладнаний вебкамерою, мікрофоном та динаміками і підключенням до мережі Інтернету;

- у слухачів немає психологічних бар'єрів, пов'язаних з публічністю процесу навчання. На вебінарі кожен учасник може поставити запитання або висловити свою думку без бар'єрів, пов'язаних із комунікабельністю, недосвідченістю і швидкістю реакції. Слухачі легко можуть ставити запитання, не соромлячись $\mathrm{i}$ не боячись реакції аудиторії;

- ефективне навчання, вебінар сприяє глибокому зануренню в процес, досягненню ефективних результатів. Окрім спілкування 3 викладачем й інтерактивною групою, технічні засоби дозволяють демонструвати на екрані супроводжуючі слайди, текстову і графічну інформацію, схеми, таблиці. Потрібну інформацію слухачі можуть зберегти на свої комп'ютери;

- вебінари не прив'язують слухачів до певних часових рамок. Для тих, хто не може бути присутнім на занятті у момент його проведення, доступний запис, який можна переглянути у будь-який слушний час [3].

Незважаючи на велику кількість переваг застосування вебінарів у системі освіти, основним недоліком використання вебінарів $€$ технічна залежність і навички організації вебінару викладачем.

Теоретично значущим для нашого дослідження $\epsilon$ умовиводи Н. Морзе, яка зазначає, що незалежно від типу заняття у процесі підготовки до проведення вебінарів доцільно звернути увагу на такі моменти: завчасна підготовка до участі й оголошення про дату і час його проведення; вибір теми, педагогічна доцільність постановки мети і завдань вебінару; добір матеріалу, який розглядатиметься на вебінарі; методична 
підготовка викладача і студентів до семінару; сценарій проведення вебінару; підведення підсумків вебінару [3].

Системи управління навчальним контентом, які ще називають системами дистанційного навчання, передбачають створення і розміщення на їх базі електронних навчальних курсів. Студент отримує персональний доступ до такої системи, який забезпечує йому можливість користуватися в будь-який зручний для нього час поданими і розміщеними там навчальними матеріалами нового зразка. Водночас він отримує не лише статичний текст в електронному форматі, а й мультимедійні й відеоресурси і сервіси для колективного використання і спілкування як в online, так і в offline режимах на зразок Вікі, форумів, блогів, вебінарів, підкастів тощо [8]. Електронні навчальні курси побудовані на базі застосування перерахованих сервісів web 2.0.

Н. Морзе й О. Ігнатенко зазначають, що впроваджуючи у навчальний процес електронний навчальний курс, навчальний заклад має можливість:

- накопичувати й аналізувати статистику навчальних досягнень студентів статистика про успішність в режимі реального часу може передаватися викладачеві, керівнику, куратору, до деканату тощо;

- стандартизувати навчальний контент - один електронний курс можуть супроводжувати декілька викладачів, наразі зміст його не змінюється, змінюється - методика навчання;

- упроваджувати систему атестації навчальних ресурсів через забезпечення дотримання певних вимог до їх подання і складу;

- оперативно адмініструвати - адміністратор навчання може оперативно надати або анулювати доступ студентові до необхідного контенту;

- забезпечувати систематичну i відкриту взаємодію викладача i студентів, студентів між собою на всіх етапах навчального процесу - під час вивчення теоретичного матеріалу, його закріплення у процесі виконання практичних завдань, обговорення проблемних ситуацій і питань, спільного виконання навчальних проектів i ïx оприлюдненого захисту, контролю результатів навчальної діяльності, рефлексії і самооцінювання навчальних досягнень студентів тощо [8].

Отже, мережні технології дозволяють: забезпечити простоту у спілкуванні і співпраці всіх учасників навчального процесу за допомогою мережних технологій, створення соціальних спільнот, засобів колективного спілкування й обміну знаннями; реально впровадити особистісно-орієнтовані технології навчання за умов докорінної зміни ролі викладача 3 основного джерела отримання знань до фасилітатора навчального процесу [7].

Проведений аналіз літератури показує, що в основу застосування мережних ресурсів у навчально-виховному процесі покладено подані нижче дидактичні функції.

1. Створення сприятливих організаційно-методичних умов для навчальної діяльності:

- реалізація принципу наочності: демонстрація динаміки процесів, що вивчаються, графічна інтерпретація досліджуваних закономірностей ((малюнки, фоторепродукція картин, живопису, архітектури та інших фотозображень навколишнього світу), умовно-графічні засоби (таблиці, схеми, блок-схем, графіки, діаграми, організаційні діаграми, карти тощо), сучасні мультимедіа (аудіо- і відеофрагменти, анімація));

- управління навчальною інформацією;

- моделювання й імітація процесів, які вивчаються і досліджуються, явищ 3 переходом у «реальність - модель» і навпаки; 
- створення і використання інформаційних баз даних, необхідних в навчальній діяльності, забезпечення доступу до навчальної інформації;

- створення стійкого пізнавального мотиву;

- багатопланове здійснення принципу єдності навчання й виховання;

- принцип диференціації й індивідуалізації навчання.

2. Покращення психолого-педагогічних умов навчальної діяльності:

- створення зацікавленості (за рахунок відображення засобів програм або вміщення в неї ігрових ситуацій);

- забезпечення адекватного емоційного стану учнів.

3. Реалізація змісту освіти в умовах інформатизації освіти.

4. Управління навчальною діяльністю i формування структури світоглядних, поведінкових і творчих якостей [9].

На основі аналізу світового досвіду застосування IКТ у навчальному процесі Л. Петухова виділяє такі типи сценаріїв, за якими може проходити навчання на базі мережних технологій.

1. Застосовувати мережні технології на занятті. Такий сценарій $є$ найпоширенішим й активно застосовується у вищих навчальних закладах. Організація аудиторної, як правило, лекційної роботи за цим сценарієм вимагає наявності апаратного забезпечення, програмного забезпечення, а також відповідної методичної і дидактичної підготовки викладача.

2. Застосування мережних технологій до i після заняття. За таким сценарієм студент відповідно до вимог викладача ознайомлюється з певним матеріалом, виконує завдання у процесі підготовки до заняття, у тому числі й лекційного. Відповідно продовжує працювати 3 матеріалами, наданими викладачем у електронному вигляді, після закінчення заняття.

3. Застосування мережних технологій на індивідуальному занятті. Кожен студент, який має комп’ютер, підключення до мережі Інтернет, працює індивідуально, виконує завдання самостійно, може обмінюватися повідомленнями з викладачем online.

4. Комплекс. Сценарій, за якого студентам надається цілий спектр можливостей застосування різних мережних технологій. Зручний для студента, але дуже трудомісткий з точки зору розробки і супроводу для викладача. Поєднує у собі попередні три сценарії застосування мережних технологій у навчальновиховному процесі: на занятті, під час підготовки до пари, опрацювання матеріалів, що представлені на сайті й до яких відкрито доступ студентам, комп'ютерне тестування і т. ін. [10, 100].

\section{4. ВИСНОВКИ ТА ПЕРСПЕКТИВИ ПОДАЛЬШИХ ДОСЛІДЖЕНЬ}

3 огляду на викладене можемо дійти висновку, що основним завданням застосування мережних технологій під час підготовки майбутніх фахівців є:

- підвищення мотивації студентів до вивчення дисципліни, до самостійної роботи;

- підвищення наочності навчального матеріалу й полегшення його сприйняття завдяки компактному і чіткому поданню навчальних відомостей;

- розвиток творчого потенціалу суб'єктів навчання, їх комунікативних здібностей, умінь експериментально-дослідницької діяльності; культури навчальної діяльності, підвищення мотивації навчання;

- інтенсифікація всіх рівнів навчально-виховного процесу;

- розширення і поглиблення змісту навчання; 
- засвоєння повного спектру понять, операцій і функцій, вільне оперування якими передбачено змістом навчальної дисципліни;

- індивідуалізація і диференціація навчання, врахування індивідуальних особливостей кожного студента;

- співробітництво викладача і студента.

Перспективи майбутніх наукових розвідок вбачаємо у дослідженні потенціалу мережних технологій для вдосконалення змісту, форм та методів підготовки студентів до застосування IКТ у навчально-виховному процесі.

\section{СПИСОК ВИКОРИСТАНИХ ДЖЕРЕЛ}

1. Кремень В. Г. Суспільство знань і якісна освіта/В. Г. Кремень // Всеукраїнський громадськополітичний тижневик «Освіта». — № 13-14. - 21-27 березня 2007 року.

2. Коваль Т. І. Підготовка викладачів вищої школи: інформаційні технології у педагогічній діяльності : навч.-метод. пос. / Т. І. Коваль, С. О. Сисоєва, Л. П. Сущенко. - К. : Вид. центр КНЛУ, 2009. - $380 \mathrm{c.}$

3. Коневщинська О. Е. Організація процесу електронного навчання з використанням технології вебінару [Електронний ресурс] /О. Е. Коневшинська // Інформаційні технології і засоби навчання. — 2011. — № (25). — Режим доступу до журналу : http://www.journal.iitta.gov.ua.

4. Winer D. The History of Weblogs [Electronic Resource] / D. Winer. - Available : http://oldweblogscomblog.scripting.com/historyOfWeblogs. - Title from monitor.

5. Палкова А. В. Применение сервисов Веб 2.0 в преподавании иностранных языков / А. В. Палкова // Преподавание иностранных языков в мультимедийном пространстве. - Тверь : Тверской гос. ун-т, 2012. - С. 69-85.

6. Яценко Ю. С. Блоги в учебном процессе [Электронный ресурс] / Ю. С. Яценко // Мастер-классы для преподавателей английского языка [Сайт]. - Режим доступа : http://internetineflt.narod.ru/MK_1_2.html. — Загл. с экрана.

7. Кухаренко В. М. Використання вебінарів у навчальному процесі / В. М. Кухаренко // Комп'ютер в школі та сім'ї. — 2011. — № 2 (90). — С. 12-16.

8. Морзе Н. В. Методичні особливості вебінарів, як інноваційної технології навчання / Н. В. Морзе, О. В. Ігнатенко // Інформаційні технології в освіті : зб. наук. пр. - Херсон : ХДУ, 2010. — Вип. 5 - C. 31-39.

9. Дорошенко Ю. О. Дидактичні функції мультимедійних технологій навчання у початковій школі / [Ю. О. Дорошенко, М. М. Левшин, Ю. С. Мельник, В. Ю. Савченко] // Тр. другої Всеукраїнської конференції молодих науковців «Інформаційні технології в науці та освіті». - Черкаси : ЧДУ ім. Б. Хмельницького, 2000. - С. 90-91.

10. Петухова Л. Є. Інформатичні компетентності майбутнього вчителя початкових класів (в моделі трисуб‘єктної дидактики) : навчально-методичний посібник. - Херсон : Херсонський державний університет, $2010 .-524$ с.

Матеріал надійшов до редакиії29.09.2013 p.

\section{ИСПОЛЬЗОВАНИЕ СЕТЕВЫХ ТЕХНОЛОГИЙ В УЧЕБНО- ВОСПИТАТЕЛЬНОМ ПРОЦЕССЕ ВУЗА}

\section{Глушак Оксана Михайловна}

преподаватель кафедры информационных технологий и математических дисциплин

Киевский университет имени Бориса Гринченко, г. Киев, Украина

oksana_glushak@ukr.net

Аннотация. В статье рассмотрены сервисы сетевых технологий, проанализированы различные способы применения вики-технологий, блогов, вебинаров, систем дистанционного обучения с созданием электронных учебных курсов, в учебновоспитательном процессе высшей школы. В результате исследования установлено, что основными задачами применения сетевых технологий в учебно-воспитательном процессе 
вуза являются: создание устойчивого познавательного мотива, развитие творческого потенциала студентов, повышение наглядности учебного материала, интенсификация всех уровней учебного процесса, расширение и углубление содержания обучения, индивидуализация и дифференциация обучения.

Ключевые слова: информатизация; информационно-коммуникационные технологии; web2.0 ; вики; блоги; вебинар.

\title{
NETWORKING TECHNOLOGIES IN THE EDUCATIONAL PROCESS OF HIGH SCHOOL
}

\author{
Oksana M. Glushak \\ lecturer of the Department of information technology and mathematic sciences \\ Borys Grinchenko Kyiv University, Kyiv, Ukraine \\ oksana_glushak@ukr.net
}

\begin{abstract}
In the article it is considered networking services, analyzed different ways to use wiki technology, blogs, webinars, distance learning system, the creation of e-learning courses in the educational process of higher education. The study determined that the main objectives of the use of network technologies in the educational process of higher education are: the creation of a sustainable educational motive, the development of the creative potential of students, enhance the visibility of educational material, intensification at all levels of the educational process, broadening and deepening the learning content, personalization and differentiation of instruction.
\end{abstract}

Keywords: informatization; information and communication technologies; web-2.0; wiki; blogs; webinar.

\section{REFERENCES (TRANSLATED AND TRANSLITERATED)}

1. Kremen' V. H. Community of knowledge and quality education / V. H. Kremen' // Vseukrayins'kyy hromads'ko-politychnyy tyzhnevyk «Osvita». - № 13-14. - 21-27 bereznya 2007 roku. (in Ukrainian)

2. Koval' T. I. Training of higher education: information technology in educational activities: navch.-metod. pos. / T. I. Koval', S. O. Sysoyeva, L. P. Sushchenko. - K. : Vyd. tsentr KNLU, 2009. - 380 s. (in Ukrainian)

3. Konevshchyns'ka O. E. Organization of using e-learning technologies webinar [online] / O. E. Konevshyns'ka // Informatsiyni tekhnolohiyi i zasoby navchannya. — 2011. — \#5 (25). — Available from : http://www.journal.iitta.gov.ua (in Ukrainian)

4. Winer D. The History of Weblogs [online] / D. Winer. - Available from : http://oldweblogscomblog.scripting.com/historyOfWeblogs. — Title from monitor. (in English)

5. Palkova A. V. The use of Web 2.0 services in the teaching of foreign languages / A. V. Palkova // Prepodavanie inostrannyh jazykov v mul'timedijnom prostranstve. — Tver' : Tverskoj gos. un-t, 2012. — S. 69-85. (in Russian)

6. Jacenko Ju. S. Blogs in the learning process [online] / Ju. S. Jacenko // Master-klassy dlja prepodavatelej anglijskogo jazyka. — Available from : http://internetineflt.narod.ru/MK_1_2.html. — Zagl. s jekrana. (in Russian)

7. Kukharenko V. M. Using webinars in the learning process / V. M. Kukharenko // Komp"yuter v shkoli ta sim"yi. - 2011. — № 2 (90). - S. 12-16. (in Ukrainian)

8. Morze N. V. Methodological features webinars as an innovative technology training / N. V. Morze, O. V. Ihnatenko // Informatsiyni tekhnolohiyi v osviti : zb. nauk. pr. — Kherson : KhDU, 2010. — Vyp. 5. — S. 31-39. (in Ukrainian)

9. Doroshenko Yu.O. Didactic function of multimedia technology education in primary schools / [Yu. O. Doroshenko, M. M. Levshyn, Yu. S. Mel'nyk, V. Yu. Savchenko] // Tr. Druhoyi Vseukrayins'koyi konferentsiyimolodykhnaukovtsiv «Informatsiyni tekhnolohiyi v nautsi ta osviti». — Cherkasy : ChDUim. B. Khmel'nyts'koho, 2000. - S. 90-91. (in Ukrainian)

10. Petukhova L. Ye. Information competence of future teachers of primary classes (in the model of tryzub'yektnoyi didactics): Navchal'no-metodychny posibnyk. - Kherson : Khersons'kyy derzhavnyy universytet, 2010. — 524 s. (in Ukrainian) 